\title{
STUDY OF ANTIMICROBIAL ACTIVITY OF THE FOLKLORE MEDICINAL PLANT, ACALYPHA FRUTICOSA FORSSK.
}

\author{
Thambiraj, J. \\ PG and Research Department of Botany, The Madura College (Autonomous), Madurai - 625011. \\ E. \\ mail: thambiraj84@gmail.com
}

\begin{abstract}
The purpose of the study is to examine the antimicrobial efficacy of root extracts of the folklore medicinal plant species, Acalypha fruticosa Forssk by using three alcoholic solvents viz; petroleum ether, ethyl acetate and methanol were tested against ten human pathogenic bacteria viz., Pseudomonas aeruginosa, $P$. stutzeri, Escherichia coli, Micrococcus sp., Lactobacillus sp., Servatia sp., Moraxetta sp., Bacillus subtilis, $B$. thuriengensis, and Klebsiella pneumoniae and ten human pathogenic fungi viz., Aspergillus niger, A. flavus, A.baumannii, Fusarium oxysporum, F. solani, Mucor rouxii, Alternaria alternata, Candida albicans, Cladosporium sp. and Rhizopus sp. for assessing the antimicrobial properties by adapting disc diffusion method. The results of the study revealed that all extracts showed varied degree of antimicrobial activity against the tested pathogens. However, the methanol extracts exhibited higher inhibition zone $(21.83 \mathrm{~mm})$ against the bacterium, Bacillus subtilis and ethyl acetate extracts showed higher inhibiotion zone $(24.83 \mathrm{~mm})$ against the fungus, Rhizopus sp. Results concluded that this spices contain high amount of secondary metabolites due to these metabolites they have high antimicrobial activity and it can be used as good bio-preservater and it can also use for medicinal purpose.
\end{abstract}

Keywords: Acalypha fruticosa, Antimicrobial activity, Disc diffusion, Microorganisms.

\section{INTRODUCTION}

Plants have been a valuable source of natural products for a long period of time to maintain human health, especially with more intensive studies in the last decade for natural therapies (Gislene et al., 2000). In many parts of the world, the extracts and essential oil of medicinal plants are used in folk medicine for their antimicrobial and antiviral properties (Hassawi and Kharma, 2006), that have been used. During the last two decades, the pharmaceutical industry has made massive investments on pharmacological, clinical and chemical researches all over the world in an effort to discover still more potent plant drugs; in fact, a few new drug plants have successfully passed the tests of commercial screening. Many of the plants used today were known to the people of ancient culture throughout the world for their preservative and medicinal powers (Zaika, 1975). However several plants are used in India in the form of crude extracts. A lot of plants with medicinal value used in the Indian traditional medicine have not yet been characterized for their active principles. Hence, one such plant of great medicinal importance is Acalypha fruticosa which are found to have diverse photochemical compounds of medicinal properties. This study plant species, Acalypha fruticosa belongs to the family, Euphorbiaceae is one such folklore plant used in traditional system of medicine in
Coimbatore district of Tamil Nadu, India. The species is mainly distributed in tropical regions of India, Arabia, peninsular Burma and Africa. In India it is abundantly present in the foot hills of the Western Ghats (Matthew, 1995). Locally in Western districts of Tamil Nadu, the plant is administered to treat the diseases like jaundice, fever, and even as an antidote. The root is used for gonorrhea. Leaves and roots are used in siddha system of medicine for the treatment of skin diseases (Pullaiah, 2006). The plant is also used to cure cough, cold and headache. The boiled roots are used to cure cerebral malaria (Sahoo, 2001). A root decoction is drunken to treat convulsions, fever, colds and swellings of the scrotum and to treat whooping cough. Root decoction is taken to snake bites, fever and ulcer of venereal origin. However, no published works are available for the antimicrobial property of root of this plant. Hence in the present study, an attempt has been made to focus the plant in this angle and hence to assess its therapeutic potency.

\section{MATERIALS AND METHODS}

\subsection{Plant material}

Fresh root parts were collected from the population of $A$. fruticosa present in the Maruthamalai Hills of Coimbatore District and washed under running tap water, air dried and then homogenized to fine powder and stored in air tight bottles. 


\subsection{Preparation of extracts}

$250 \mathrm{~g}$ air-dried root powder was subjected to $250 \mathrm{ml}$ of methanol in soxhlet extraction for 8 hours $\left(50-85^{\circ} \mathrm{C}\right)$. The extracts were concentrated to dryness in a flask evaporator under reduced pressure and controlled temperature $\left(50-60^{\circ} \mathrm{C}\right)$ to yield crude residue, which was then stored in refrigerator. To obtain petroleum ether and ethyl acetate extracts, the same method as used to obtain methanol extract was adopted.

\subsection{Media used}

Freshly prepared Nutrient Agar medium and PDA medium were used for the culture of bacteria and fungi respectively.

\subsection{Microorganisms}

In vitro antimicrobial activity was examined for the chemical extracts of root part of the study plant, against ten bacterial species which include the gram positive strains viz., Micrococcus sp., Lactobacillus sp., Bacillus subtilis, B. thuriengensis and gram negative strains viz., Pseudomonas aeruginosa, P. stutzeri, Escherichia coli, Klebsiella pneumoniae, Servatia sp. and Moraxetta sp. and fungal species viz., Aspergillus niger, A. flavus, $A$. baumannii, Fusarium oxysporum, F. solani, Mucor rouxii, Alternaria alternata, Candida albicans, Cladosporium sp. and Rhizopus sp. All these microorganisms were obtained from the Department of Microbiology, Tamil Nadu Agricultural University, Coimbatore. All the microorganisms were maintained at $4^{\circ} \mathrm{C}$ on nutrient agar slants (for bacteria) and PDA slants (for fungi) until furtheruse.

\subsection{Antimicrobial assay}

The alcoholic extracts were tested for their effect against the growth of pathogenic bacteria and fungi by disc diffusion method (Bauer et al., 1966). Both the organisms, bacteria and fungi tested were inoculated into nutrient agar and PDA media respectively. After an incubation period of $24 \mathrm{hrs}$ at a temperature of $35^{\circ} \mathrm{C}$, three or four colonies isolated from these media were inoculated into $4 \mathrm{ml}$ of nutrient broth and incubated for $2 \mathrm{hrs}$ at $35^{\circ} \mathrm{C}$. The cultures were adjusted with sterile saline solution to obtain turbidity. Petri dishes containing MullerHinton agar medium and PDA medium were streaked with these microbial suspensions of bacteria and fungi respectively. Disks of $6 \mathrm{~mm}$ diameter were impregnated with the extracts of petroleum ether, methanol and ethyl acetate separately. Tetracycline is used as positive control. After equilibrium at $4^{\circ} \mathrm{C}$, the plates were incubated overnight at $37^{\circ} \mathrm{C}$ and the diameter of any resulting zones of inhibition was measured. Each experiment was repeated at least three times.

\section{RESULTS AND DISCUSSION}

The antibacterial activity of the all the alcoholic root extracts of the study species, Acalypha fruticosa generally ethyl acetate extracts showed inhibitory activity against all the bacterial growth and methanol extracts showed inhibitory activity against Bacillus subtilis, B. thuringiensis, Micrococcus sp., Lactobacillus sp., Klebsiella pneumonia, Escherichia coli, Pseudomonas aeruginosa and $P$. stutzeri except Serratia sp. and Moraxetta sp. However, petroleum ether extracts has comparatively less activity against most of the tested pathogens (Table 1). It is explained that the different phytochemicals like alkaloids, flavonoids, glycosides, saponins, terpenoids etc., which have extracted by different solvents may be responsible for their antibacterial effects (Anandakumar et al., 2009). Further, the methanol extract has determined to have highest inhibitory activity $(21.83 \mathrm{~mm}$ diameter inhibitory zone) against the bacterium, Bacillus subtilis (gram positive) and (20.63 $\mathrm{mm}$ diameter inhibitory zone) against the bacterium, Bacillus thuringiensis followed by the ethyl acetate extract against the bacterium, Bacillus subtilis (gram positive) (16.13 $\mathrm{mm}$ diameter inhibitory zone). It indicates the presence of effective active principle compounds in the ethyl acetate and methanol extracts of root part of $A$. fruticosa to suppress both gram negative and gram positive bacteria. It has been observed further that the methanol extracts showed significant inhibitory activity against the colonial growth of Bacillus subtilis, B. thuringiensis, Klebsiella pneumonia when compare with the commercially available antibiotic, tetracycline. This fact shows the higher therapeutic potential of methanol and ethyl acetate extracts of the study species. The petroleum ether extract has comparatively less activity against most of the tested pathogens. It may be attributed to the presence of respective active compounds with insufficient quantities in this crude extract (Taylor et al., 2001).

The antifungal activity of various alcoholic root extracts of the study species, Acalypha fruticosa against the ten studied fungal species is given in Table 2 . The results of the study report that the ethyl acetate extract has the highest inhibitory activity (24.83 $\mathrm{mm}$ diameter inhibitory zone) against the fungus, Rhizopus sp. and the methanol extract has the higher inhibitory activity $(15.73 \mathrm{~mm}$ diameter inhibitory zone) against the fungus, Fusarium solani. The petroleum ether extract has comparatively less activity against most of the tested pathogens. 
Table 1. Antibacterial activity of certain alcoholic root extracts of the species, Acalypha fruticosa.

\begin{tabular}{|c|c|c|c|c|c|c|c|c|c|c|}
\hline \multirow{3}{*}{$\begin{array}{c}\text { Plant } \\
\text { extract }\end{array}$} & \multicolumn{10}{|c|}{ Diameter of zone inhibition (mm) } \\
\hline & \multicolumn{4}{|c|}{ Gram positive bacteria } & \multicolumn{6}{|c|}{ Gram negative bacteria } \\
\hline & $\begin{array}{l}\text { Bacillus } \\
\text { subtilis }\end{array}$ & $\begin{array}{c}B . \\
\text { thuringiensis }\end{array}$ & $\begin{array}{l}\text { Micrococ } \\
\text { cus sp. }\end{array}$ & $\begin{array}{l}\text { Lactobacillu } \\
\text { s sp. }\end{array}$ & $\begin{array}{c}\text { Klebsiella } \\
\text { pneumoniae }\end{array}$ & $\begin{array}{c}\text { Escherichia } \\
\text { coli }\end{array}$ & $\begin{array}{c}\text { Pseudomonas } \\
\text { stutzeri }\end{array}$ & $\begin{array}{c}P . \\
\text { aeruginosa }\end{array}$ & $\begin{array}{l}\text { Serratia } \\
\text { sp. }\end{array}$ & $\begin{array}{c}\text { Moraxe } \\
\text { tta sp. }\end{array}$ \\
\hline Standard * & $\begin{array}{c}30.83 \pm \\
0.80\end{array}$ & $30.73 \pm 0.67$ & $\begin{array}{c}20.67 \pm \\
0.59\end{array}$ & $23.63 \pm 0.60$ & $12.13 \pm 0.71$ & $25.67 \pm 0.61$ & $13.73 \pm 0.67$ & $21.73 \pm 0.70$ & $\begin{array}{c}14.23 \pm \\
0.49\end{array}$ & $\begin{array}{c}20.83 \pm \\
0.80\end{array}$ \\
\hline $\begin{array}{l}\text { Petroleum } \\
\text { ether }\end{array}$ & $\begin{array}{c}9.67 \pm \\
0.75\end{array}$ & - & - & - & $8.13 \pm 0.71$ & - & - & $7.32 \pm 0.49$ & - & - \\
\hline $\begin{array}{c}\text { Ethyl } \\
\text { acetate }\end{array}$ & $\begin{array}{c}16.13 \pm \\
0.38\end{array}$ & $15.16 \pm 0.38$ & $\begin{array}{c}9.73 \pm \\
0.67\end{array}$ & $10.73 \pm 0.67$ & $8.77 \pm 0.71$ & $8.73 \pm 0.75$ & $9.77 \pm 0.75$ & $11.73 \pm 0.67$ & $\begin{array}{c}7.77 \pm \\
0.71\end{array}$ & $\begin{array}{c}8.77 \pm \\
0.71\end{array}$ \\
\hline Methanol & $\begin{array}{c}21.83 \pm \\
0.60\end{array}$ & $20.63 \pm 0.60$ & $\begin{array}{c}8.06 \pm \\
0.31\end{array}$ & $8.63 \pm 0.60$ & $10.16 \pm 0.47$ & $9.67 \pm 0.58$ & $9.76 \pm 0.86$ & $7.67 \pm 0.61$ & - & - \\
\hline
\end{tabular}

*Tetracycline

Table 2. Antifungal activity of certain alcoholic root extracts of the species, Acalypha fruticosa.

\begin{tabular}{|c|c|c|c|c|c|c|c|c|c|c|}
\hline \multirow{2}{*}{$\begin{array}{c}\text { Plant } \\
\text { extract }\end{array}$} & \multicolumn{10}{|c|}{ Diameter of zone inhibition (mm) } \\
\hline & $\begin{array}{c}\text { Aspergillus } \\
\text { niger }\end{array}$ & A. flavus & $\begin{array}{c}\text { A. } \\
\text { baumanii }\end{array}$ & $\begin{array}{c}\text { Fusarium } \\
\text { oxysporum }\end{array}$ & F. solani & $\begin{array}{l}\text { Mucor } \\
\text { rouxii }\end{array}$ & $\begin{array}{r}\text { Alternaria } \\
\text { alternata }\end{array}$ & $\begin{array}{l}\text { Candida } \\
\text { albicans }\end{array}$ & $\begin{array}{l}\text { Cladosporium } \\
\text { sp. }\end{array}$ & $\begin{array}{l}\text { Rhizopus } \\
\text { sp. }\end{array}$ \\
\hline $\begin{array}{c}\text { Standard } \\
*\end{array}$ & $45.77 \pm 0.61$ & $\begin{array}{c}39.87 \pm \\
0.85\end{array}$ & $\begin{array}{c}41.73 \pm \\
0.70\end{array}$ & $44.53 \pm 0.68$ & $\begin{array}{c}23.73 \pm \\
0.75\end{array}$ & $40.76 \pm 0.80$ & $42.83 \pm 0.80$ & $12.73 \pm 0.70$ & $44.73 \pm 0.67$ & $33.73 \pm 0.70$ \\
\hline $\begin{array}{l}\text { Petroleum } \\
\text { ether }\end{array}$ & $9.76 \pm 0.58$ & $8.83 \pm 0.80$ & $\begin{array}{c}8.76 \pm \\
0.80\end{array}$ & $7.67 \pm 0.49$ & $8.76 \pm 0.80$ & $7.87 \pm 0.85$ & - & - & $9.43 \pm 0.65$ & $7.83 \pm 0.80$ \\
\hline $\begin{array}{c}\text { Ethyl } \\
\text { acetate }\end{array}$ & $20.67 \pm 0.53$ & $13.87 \pm 0.90$ & $\begin{array}{c}14.83 \pm \\
0.91\end{array}$ & $10.83 \pm 0.85$ & $\begin{array}{c}10.76 \pm \\
0.65\end{array}$ & $\begin{array}{c}14.73 \pm \\
0.70\end{array}$ & $10.76 \pm 0.75$ & - & $13.76 \pm 0.80$ & $24.83 \pm 0.90$ \\
\hline Methanol & $12.77 \pm 0.58$ & $8.73 \pm 0.75$ & $\begin{array}{c}9.77 \pm \\
0.80\end{array}$ & - & $\begin{array}{c}15.73 \pm \\
0.75\end{array}$ & $9.77 \pm 0.75$ & $8.77 \pm 0.80$ & $7.83 \pm 0.91$ & $8.76 \pm 0.70$ & $10.73 \pm 0.70$ \\
\hline
\end{tabular}

*Tetracycline

This fact indicats the existence of strong antifungal activity of root part of the study species, $A$. fruticosa and hence its effective healing property against the infectious diseases. The variation in antifungal activity across the extracts studied may be due to the polarity of the solvents used. Significantly higher inhibitory activity of ethyl acetate extract is nearly to the commercially available antibiotic tetracycline against the fungus, Rhizopus sp. observed shows the superior healingness of root part of $A$. fruticosa. Proper isolation and purification of active compounds by using ethyl acetate solvent would ensure the therapeutic value of this folklore medicinal plant when it will be used commercially. 
The overall study on antimicrobial activity reports that the study species contains adequate variety of active compounds to reduce or check the growth of microbial colonies. It confirms the therapeutic value and hence the traditional usage of the root part of the study species, A. fruticosa against various ailments. Further, the alcoholic extracts of root part of this plant in general and ethyl acetate and methanol extracts in particular are suggested for the therapy of infectious diseases caused by pathogens and further studies are recommended to purify the active compounds for the formulation of new drugs, while go for commercialization.

\section{ACKNOWLEDGEMENT}

The authors are gratefully acknowledging the authorities of Tamil Nadu State Council for Science and Technology, Chennai for their financial assistance to carryout the work.

\section{REFERENCES}

Anandakumar, A.M., S. Paulsamy, P. Sathishkumar and P. Senthilkumar, (2009). Preliminary phytochemical studies for the quantification of secondary metabolites of medicinal importance in the plant, Acalypha fruticosa Forssk. Journal of Applied and Natural Science 1(1): 41-43.

Bauer, R.W., M.D.K. Kirby, J.C. Sherris and M. Turek, (1966). Antibiotic susceptibility testing by standard single disc diffusion method. American Journal of Clinical Pathology 45: 493-496.

Gislene, G.F.N., L. Juliana, C.F. Paulo and L.S. Giuliana, (2000). Antibacterial Activity of plant extracts and phytochemicals on antibiotic resistant Bacteria. Brazilian J. Microbiology. 31: 247-256.

Hassawi, D. and A. Kharma, (2006). Antimicrobial activity of some medicinal plants against Candida albicans. Journalof Biological Sciences 6: 109-114.

Matthew, K.M. (1995). The Flora of the Tamilnadu Carnatic. (Rapinat Herbarium: Tiruchirapalli).

Pullaiah, T. (2006). Encyclopaedia of World Medicinal Plants, Daya Books, pp.1-2442.

Sahoo, 2001. Conservation and Utilization of Medicinal and Aromatic Plants, Allied Publishers, p. 80.

Taylor, J.L., S.T. Rabe, L.J. McGraw, A.K. Jager and J. van Staden, (2001). Towards the Scientific Validation of traditional medicinal plants, Plant Growth Regul. 34: 23-37.

Zaika, L.I. 1975. Spices and Herbs, their antimicrobial activity and its determination. Journal of Food Safety 9: 97-118. 